\title{
Total Synthesis of Luotonin A and Rutaecarpine from an Aldimine via the Designed Cyclization
}

\author{
Se Hyun Kwon, Hong-Ahn Seo and Cheol-Hong Cheon* \\ Department of Chemistry, Korea University, 145 Anam-ro, Seongbuk-gu, Seoul 02841, Republic of Korea
}

Table of Contents

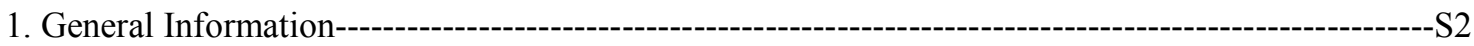

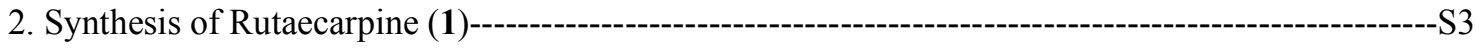

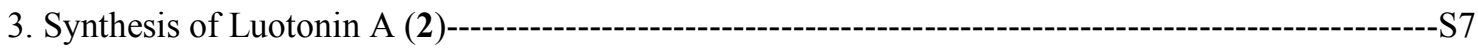

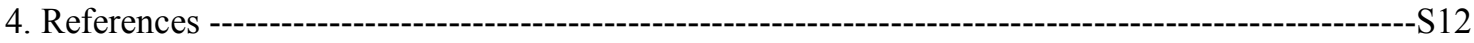

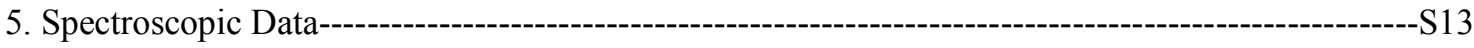




\section{General Information}

All reactions were carried out in oven-dried glassware under an argon atmosphere unless otherwise noted. Except as otherwise indicated, all reactions were magnetically stirred and monitored by analytical thin layer chromatography (TLC) using pre-coated silica gel glass plates $(0.25 \mathrm{~mm})$ with F254 indicator. Visualization was accomplished by UV light $(254 \mathrm{~nm})$, with combination of potassium permanganate and/or phosphomolybdic acid solution as an indicator. Flash column chromatography was performed using silica gel 60 (230 - 400 mesh). Yields refer to chromatographically and spectroscopically pure compounds, unless otherwise noted. Commercial grade reagents and solvents were used without further purification. (E)-2-Aminocinnamic acid ethyl ester $\mathbf{6}$ and quinazolinone-2carbaldehyde 7 were prepared by the reported procedures, respectively. ${ }^{1,2}{ }^{1} \mathrm{H}$ NMR and ${ }^{13} \mathrm{C}$ NMR spectra were recorded on $400 / 500 \mathrm{MHz}$ and $100 / 125 \mathrm{MHz}$ spectrometers, respectively. Tetramethylsilane $(\delta: 0.0 \mathrm{ppm})$ and a residual NMR solvent (either $\mathrm{CDCl}_{3}(\delta \mathrm{c}: 77.16 \mathrm{ppm})$ or DMSO $\left.\left(\delta_{\mathrm{C}}: 39.52 \mathrm{ppm}\right)\right)$ were used as internal standards for ${ }^{1} \mathrm{H}$ NMR and ${ }^{13} \mathrm{C}$ NMR spectra, respectively. The proton spectra are reported as follows $\delta$ (position of proton, multiplicity, coupling constant $J$, number of protons). Multiplicities are indicated by s (singlet), d (doublet), t (triplet), q (quartet), p (quintet), h (septet), m (multiplet) and br (broad). High resolution mass spectra (HRMS) were recorded on quadrupole time-of-flight mass spectrometer (QTOF-MS) using electrospray ionization (ESI) as an ionization method. 


\section{Total Synthesis of Rutaecarpine (1)}

\section{2-1. Synthesis of Aldimine 5}<smiles>CCOC(=O)/C=C/c1ccccc1N</smiles>

6

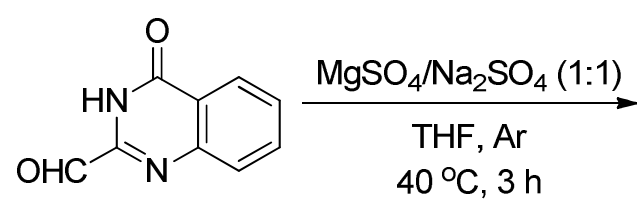

7<smiles>CCOC(=O)/C=C/c1ccccc1/N=C/c1nc2ccccc2c(=O)[nH]1</smiles>

To a $100 \mathrm{~mL}$ round bottom flask were added $(E)$-2-aminocinnamic acid ethyl ester 6 (1.3 g, $7.0 \mathrm{mmol})$, quinazolinone-2-carbaldehyde $7(1.2 \mathrm{~g}, 7.0 \mathrm{mmol})$, magnesium sulfate $(2.0 \mathrm{~g})$ and sodium sulfate $(2.0$ g). Then, dry THF $(35 \mathrm{~mL})$ was added to the above flask. The reaction mixture was allowed to stir at $40{ }^{\circ} \mathrm{C}$ under an argon atmosphere and monitored by ${ }^{1} \mathrm{H}$ NMR. After complete consumption of the starting materials, insoluble solids were removed by filtration. The filtrate was concentrated in vacuo and recrystallized in a mixture of cooled dichloromethane and hexanes to afford the desired aldimine 5 as an orange solid in $95 \%$ yield $(2.3 \mathrm{~g})$.

${ }^{1} \mathrm{H}$ NMR (400 MHz, $\left.\mathrm{CDCl}_{3}, \mathrm{ppm}\right) \delta 10.41(\mathrm{br}, 1 \mathrm{H}), 8.37(\mathrm{~d}, J=7.8 \mathrm{~Hz}, 1 \mathrm{H}), 8.27(\mathrm{~s}, 1 \mathrm{H}), 8.19(\mathrm{~d}, J=$ $16.0 \mathrm{~Hz}, 1 \mathrm{H}), 7.84(\mathrm{~d}, J=3.5 \mathrm{~Hz}, 2 \mathrm{H}), 7.71(\mathrm{~d}, J=7.8 \mathrm{~Hz}, 1 \mathrm{H}), 7.57-7.61(\mathrm{~m}, 1 \mathrm{H}), 7.46(\mathrm{t}, J=7.4 \mathrm{~Hz}$, $1 \mathrm{H}), 7.39$ (t, $J=7.4 \mathrm{~Hz}, 1 \mathrm{H}), 7.13(\mathrm{~d}, J=7.8 \mathrm{~Hz}, 1 \mathrm{H}), 6.45(\mathrm{~d}, J=16.0 \mathrm{~Hz}, 1 \mathrm{H}), 4.24(\mathrm{q}, J=7.0 \mathrm{~Hz}$, $2 \mathrm{H}), 1.32(\mathrm{t}, J=7.0 \mathrm{~Hz}, 3 \mathrm{H})$.

${ }^{13} \mathrm{C}$ NMR (100 MHz, $\mathrm{CDCl}_{3}$, ppm) $\delta 166.8,160.8,153.6,148.6,148.1,147.5,140.0,135.0,131.4$, $129.9,128.9,128.7,128.6,127.5,127.2,123.3,120.6,118.7,60.9,14.5$. 


\section{2-2. Synthesis of Indole 3}<smiles>CCOC(=O)/C=C/c1ccccc1/N=C/c1nc2ccccc2c(=O)[nH]1</smiles>

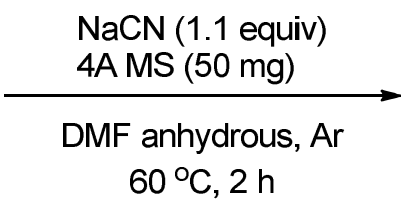

$60^{\circ} \mathrm{C}, 2 \mathrm{~h}$

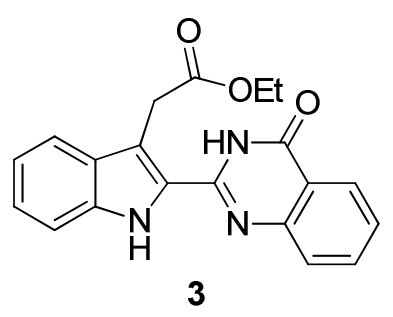

3

To a $25 \mathrm{~mL}$ round bottom flask were added aldimine $5(0.17 \mathrm{~g}, 0.50 \mathrm{mmol}), 4 \AA$ molecular sieves (50 $\mathrm{mg}$ ) and sodium cyanide (27 mg, $0.55 \mathrm{mmol})$. Anhydrous DMF $(2.5 \mathrm{~mL})$ was added to the above flask. The reaction mixture was stirred at $60{ }^{\circ} \mathrm{C}$ under an argon atmosphere and monitored by TLC. After complete consumption of aldimine $\mathbf{5}$, the reaction mixture was filtered to remove insoluble solids. The filtrate was concentrated in vacuo to provide the crude product of indole $\mathbf{3}$. The resulting crude mixture was purified by column chromatography on silica using a gradient eluent from ethyl acetate:hexanes $=1: 5$ to dichloromethane:methanol $=100: 1$ to provide the desired indole 3 as a white solid in $77 \%$ yield $(0.13 \mathrm{~g})$.

${ }^{1} \mathrm{H}$ NMR (400 MHz, DMSO-d 6 , ppm) $\delta 12.18$ (br, 1H), 11.70 (br, 1H), 8.13 (d, $\left.J=7.8 \mathrm{~Hz}, 1 \mathrm{H}\right), 7.84$ (t, $J=7.6 \mathrm{~Hz}, 1 \mathrm{H}), 7.71(\mathrm{~d}, J=7.8 \mathrm{~Hz}, 1 \mathrm{H}), 7.63(\mathrm{~d}, J=7.8 \mathrm{~Hz}, 1 \mathrm{H}), 7.46-7.54(\mathrm{~m}, 2 \mathrm{H}), 7.28(\mathrm{t}, J=$ $7.4 \mathrm{~Hz}, 1 \mathrm{H}), 7.12(\mathrm{t}, J=7.6 \mathrm{~Hz}, 1 \mathrm{H}), 4.28(\mathrm{~s}, 2 \mathrm{H}), 4.04$ (q, $J=7.0 \mathrm{~Hz}, 2 \mathrm{H}), 1.14$ (t, $J=7.0 \mathrm{~Hz}, 3 \mathrm{H})$.

${ }^{13} \mathrm{C}$ NMR (100 MHz, DMSO-d 6 , ppm) $\delta 171.5,161.6,148.9,147.0,135.9,134.8,128.2,127.1,126.6$, $126.4,125.9,124.4,120.5,120.0,119.8,113.4,112.1,60.1,31.1,14.2$.

HRMS (ESI) calcd for $\mathrm{C}_{20} \mathrm{H}_{17} \mathrm{~N}_{3} \mathrm{O}_{3} \mathrm{Na} 370.1168$, found 370.1162 . 


\section{2-3. Synthesis of Compound 8}

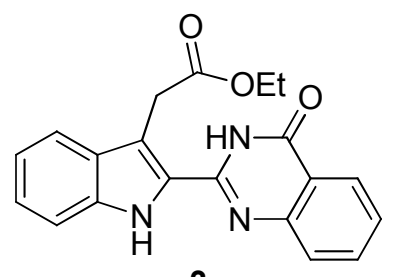

3

$$
\underset{\text { THF }, \mathrm{Ar}, \mathrm{rt}, 1 \mathrm{~h}}{\stackrel{\mathrm{LiAlH}}{4}(1.1 \text { equiv })}
$$

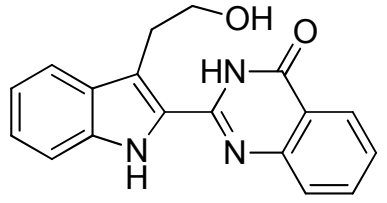

8

To a stirred solution of indole $3(70 \mathrm{mg}, 0.20 \mathrm{mmol})$ in dry THF $(2.0 \mathrm{~mL})$ was added lithium aluminum hydride $(2.0 \mathrm{M}$ solution in THF, $0.11 \mathrm{~mL}, 0.22 \mathrm{mmol})$. The reaction mixture was stirred at room temperature under an argon atmosphere and monitored by TLC. Upon the complete consumption of indole $\mathbf{3}$, the reaction mixture was quenched with water and concentrated under vacuo. The reaction mixture was diluted with water and ethyl acetate, and then $15 \%$ aqueous $\mathrm{NaOH}$ solution $(0.60 \mathrm{~mL})$ was added to the above reaction mixture to disaggregate the aluminum gel. After being vigorously stirred for an hour, the reaction mixture was extracted with ethyl acetate. The organic layer was combined, dried over anhydrous $\mathrm{MgSO}_{4}$, and concentrated in vacuo. The residue was purified by column chromatography on silica (dichloromethane:methanol $=100: 1$ ) to afford the desired product 8 as a white solid in $85 \%$ yield $(52 \mathrm{mg})$.

${ }^{1} \mathrm{H}_{\mathrm{NMR}}\left(500 \mathrm{MHz}, \mathrm{DMSO}_{\mathrm{d}}\right.$, ppm) $\delta 11.59$ (br, 1H), $8.16(\mathrm{~d}, J=7.6 \mathrm{~Hz}, 1 \mathrm{H}), 7.86(\mathrm{t}, J=7.3 \mathrm{~Hz}$, 1H), $7.74(\mathrm{~d}, J=7.9 \mathrm{~Hz}, 1 \mathrm{H}), 7.67$ (d, $J=7.8 \mathrm{~Hz}, 1 \mathrm{H}), 7.46-7.55(\mathrm{~m}, 2 \mathrm{H}), 7.25$ (t, $J=7.4 \mathrm{~Hz}, 1 \mathrm{H})$, 7.09 (t, $J=7.3 \mathrm{~Hz}, 1 \mathrm{H}), 3.87$ (t, $J=7.3 \mathrm{~Hz}, 2 \mathrm{H}), 3.23(\mathrm{t}, J=7.3 \mathrm{~Hz}, 2 \mathrm{H})$.

${ }^{13} \mathrm{C}$ NMR (125 MHz, DMSO-d 6 , ppm) $\delta 161.5,149.1,147.4,136.4,134.6,128.1,127.7,127.1,126.3$, $126.0,124.0,121.0,119.5,119.4,115.6,112.1,61.5,27.0$.

HRMS (ESI) calcd for $\mathrm{C}_{18} \mathrm{H}_{15} \mathrm{~N}_{3} \mathrm{O}_{2} \mathrm{Na} 328.1062$, found 328.1056 . 


\section{2-4. Synthesis of Rutaecarpine (1)}

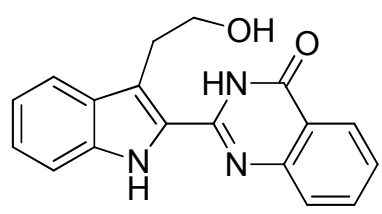

8

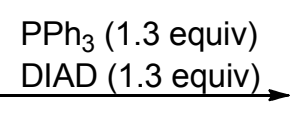

THF, rt, $1 \mathrm{~h}$

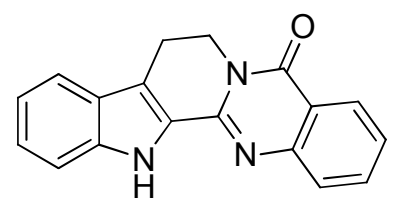

Rutaecarpine (1)

To a solution of compound $\mathbf{8}(31 \mathrm{mg}, 0.10 \mathrm{mmol})$ and triphenylphosphine ( $34 \mathrm{mg}, 0.13 \mathrm{mmol})$ in THF $(1.0 \mathrm{~mL})$ was added diisopropyl azodicarboxylate (DIAD, $22 \mu \mathrm{L}, 0.13 \mathrm{mmol}$ ). The reaction mixture was stirred at room temperature and monitored by TLC. After complete consumption of compound $\mathbf{8}$, the desired product (1) was precipitated in the reaction mixture. The precipitation was collected by filtration to provide rutaecarpine (1) as a white crystal in $48 \%$ yield. The filtrate was further purified by column chromatography on silica (dichloromethane:methanol $=50: 1$ ) to afford the desired product 1 in 13\% yield. (overall yield : 61\% yield, $18 \mathrm{mg}$ ).

Spectroscopic data were in good agreement with the literature. ${ }^{3}$

${ }^{1} \mathrm{H}$ NMR $\left(400 \mathrm{MHz}, \mathrm{CDCl}_{3}, \mathrm{ppm}\right) \delta 9.51(\mathrm{br}, 1 \mathrm{H}), 8.33(\mathrm{~d}, J=7.8 \mathrm{~Hz}, 1 \mathrm{H}), 7.62-7.72(\mathrm{~m}, 3 \mathrm{H}), 7.42(\mathrm{t}$, $J=6.8 \mathrm{~Hz}, 1 \mathrm{H}), 7.29-7.37$ (m, 2H), 7.17 (t, $J=7.2 \mathrm{~Hz}, 1 \mathrm{H}), 4.59$ (t, $J=6.9 \mathrm{~Hz}, 2 \mathrm{H}), 3.24$ (t, $J=6.9$ $\mathrm{Hz}, 2 \mathrm{H})$.

${ }^{13} \mathrm{C}$ NMR (100 MHz, $\mathrm{CDCl}_{3}$, ppm) $\delta 161.8,147.6,145.1,138.4,134.5,127.4,127.3,126.7,126.4$, $125.8,125.7,121.3,120.8,120.2,118.5,112.2,41.3,19.8$. 


\section{Total Synthesis of Luotonin A (2)}

\section{3-1. Synthesis of Quinoline 4}

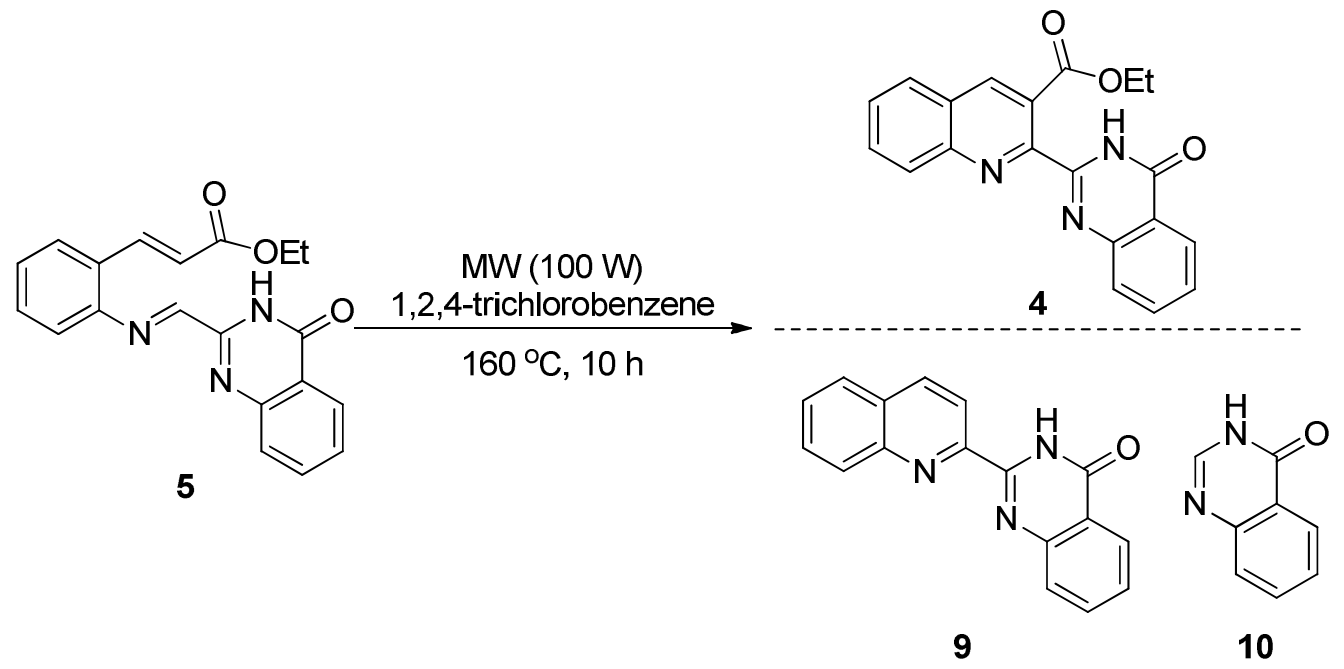

To a $35 \mathrm{~mL}$ Pyrex cell, aldimine $5(0.35 \mathrm{~g}, 1.0 \mathrm{mmol})$ was dissolved in 1,2,4-trichlorobenzene (5.0 $\mathrm{mL}$ ) and the Pyrex cell was sealed with a PTFE cap. The reaction mixture was irradiated in a microwave reactor $(100 \mathrm{~W}, 150 \mathrm{psi})$ at $160{ }^{\circ} \mathrm{C}$ for 10 hours. After 10 hours, the reaction mixture was cooled to room temperature and purified by column chromatography on silica. Initially, hexanes were used as the sole eluent to remove 1,2,4-trichlorobenzene. After removal of the solvent, the eluent was changed to a mixture of ethyl acetate and hexanes (1:3) to provide the desired quinoline $4\left(\mathrm{R}_{f}=0.50\right.$ at eluent of ethyl acetate:hexanes $=1: 1)$ as an orange solid in $42 \%$ yield $(0.15 \mathrm{~g})$. In addition to the desired product 4, the two side-products $9\left(\mathrm{R}_{f}=0.64\right.$ at eluent of ethyl acetate:hexanes $\left.=1: 1\right)$ and $\mathbf{1 0}$ $\left(\mathrm{R}_{f}=0.10\right.$ at eluent of ethyl acetate:hexanes $\left.=1: 1\right)$ were concomitantly obtained in $12 \%$ and $15 \%$, respectively. 


\section{Compound 4}

Spectroscopic data were in good agreement with the literature. ${ }^{4}$

${ }^{1} \mathrm{H}$ NMR (400 MHz, $\left.\mathrm{CDCl}_{3}, \mathrm{ppm}\right) \delta 11.03(\mathrm{br}, 1 \mathrm{H}), 8.40(\mathrm{~s}, 1 \mathrm{H}), 8.38$ (d, $\left.J=7.9 \mathrm{~Hz}, 1 \mathrm{H}\right), 8.18$ (d, $J$ $=8.4 \mathrm{~Hz}, 1 \mathrm{H}), 7.93(\mathrm{~d}, J=8.1 \mathrm{~Hz}, 1 \mathrm{H}), 7.87(\mathrm{t}, J=8.3 \mathrm{~Hz}, 1 \mathrm{H}), 7.80(\mathrm{t}, J=8.3 \mathrm{~Hz}, 1 \mathrm{H}), 7.74-7.76(\mathrm{~m}$, $1 \mathrm{H}), 7.70(\mathrm{t}, J=7.2 \mathrm{~Hz}, 1 \mathrm{H}), 7.55(\mathrm{t}, J=8.0 \mathrm{~Hz}, 1 \mathrm{H}), 4.55(\mathrm{q}, J=7.0 \mathrm{~Hz}, 2 \mathrm{H}), 1.36(\mathrm{t}, J=7.2 \mathrm{~Hz}$, $3 \mathrm{H})$.

${ }^{13} \mathrm{C}$ NMR (100 MHz, $\mathrm{CDCl}_{3}$, ppm) $\delta 168.6,161.5,148.5,148.0,146.6,145.0,137.3,134.8,131.8$, $129.7,129.3,128.2,128.1,128.0,127.8,127.1,126.9,122.7,62.3,14.3$.

\section{Compound 9}

Spectroscopic data were in good agreement with the literature. ${ }^{5}$

${ }^{1} \mathrm{H}$ NMR $\left(500 \mathrm{MHz}, \mathrm{CDCl}_{3}, \mathrm{ppm}\right) \delta 11.24(\mathrm{br}, 1 \mathrm{H}), 8.68(\mathrm{~d}, J=8.5 \mathrm{~Hz}, 1 \mathrm{H}), 8.39$ (t, $\left.J=8.2 \mathrm{~Hz}, 2 \mathrm{H}\right)$, $8.18(\mathrm{~d}, J=8.5 \mathrm{~Hz}, 1 \mathrm{H}), 7.93(\mathrm{~d}, J=8.4 \mathrm{~Hz}, 1 \mathrm{H}), 7.90$ (d, $J=8.0 \mathrm{~Hz}, 1 \mathrm{H}), 7.83$ (dddd, $J=8.3,7.0$, $2.8,1.5 \mathrm{~Hz}, 2 \mathrm{H}), 7.67(\mathrm{t}, J=8.0 \mathrm{~Hz}, 1 \mathrm{H}), 7.56(\mathrm{t}, J=8.1 \mathrm{~Hz}, 1 \mathrm{H})$.

\section{Compound 10}

Spectroscopic data were in good agreement with the literature. ${ }^{6}$

${ }^{1} \mathrm{H}$ NMR (500 MHz, DMSO-d 6 , ppm) $\delta 12.24$ (br, 1H), 8.13 (dd, $J=7.9,1.2 \mathrm{~Hz}, 1 \mathrm{H}$ ), 8.09 (s, 1H), 7.82 (ddd, $J=8.4,6.9,1.5 \mathrm{~Hz}, 1 \mathrm{H}), 7.68(\mathrm{~d}, J=8.1 \mathrm{~Hz}, 1 \mathrm{H}), 7.53$ (t, $J=7.9 \mathrm{~Hz}, 1 \mathrm{H})$. 


\section{3-2. Synthesis of Compound 11}<smiles>CCOC(=O)c1cc2ccccc2nc1-c1nc2ccccc2c(=O)[nH]1</smiles>

To a stirred solution of quinoline $4(0.17 \mathrm{~g}, 0.50 \mathrm{mmol})$ in a mixture of $\mathrm{MeOH}$ and $\mathrm{H}_{2} \mathrm{O}(5.0 \mathrm{~mL}, 10: 1$ (v/v)) was added potassium hydroxide $(0.28 \mathrm{~g}, 5.0 \mathrm{mmol})$. The reaction mixture was stirred at $50{ }^{\circ} \mathrm{C}$ and monitored by TLC. Upon the complete consumption of the starting material $\mathbf{4}$, the reaction mixture was neutralized with $1.0 \mathrm{~N} \mathrm{HCl}$ and extracted with ethyl acetate. The organic layer was combined, dried over anhydrous $\mathrm{MgSO}_{4}$, and concentrated in vacuo to afford the desired product $\mathbf{1 1}$ as a white solid in $93 \%$ yield $(0.15 \mathrm{~g})$.

${ }^{1} \mathrm{H}$ NMR (500 MHz, DMSO-d 6 , ppm) $\delta 9.02(\mathrm{~s}, 1 \mathrm{H}), 8.27$ (d, $J=8.2 \mathrm{~Hz}, 1 \mathrm{H}$ ), $8.23(\mathrm{dd}, J=7.3,1.2$ $\mathrm{Hz}, 1 \mathrm{H}), 8.19$ (d, $J=8.4 \mathrm{~Hz}, 1 \mathrm{H}), 7.99$ (td, $J=8.3,1.2 \mathrm{~Hz}, 1 \mathrm{H}), 7.87$ (td, $J=8.5,1.5 \mathrm{~Hz}, 1 \mathrm{H}), 7.82$ (t, $J=8.0 \mathrm{~Hz}, 1 \mathrm{H}), 7.62(\mathrm{~d}, J=7.9 \mathrm{~Hz}, 1 \mathrm{H}), 7.59$ (t, $J=8.1 \mathrm{~Hz}, 1 \mathrm{H})$.

${ }^{13} \mathrm{C}$ NMR (125 MHz, DMSO-d 6 , ppm) $\delta 166.8,161.3,152.8,150.5,148.2,146.9,139.2,134.6,132.4$, $129.1,128.9,128.7,127.2,127.1,126.9,126.0,125.1,121.6$.

HRMS (ESI) calcd for $\mathrm{C}_{18} \mathrm{H}_{11} \mathrm{~N}_{3} \mathrm{O}_{3} \mathrm{Na} 340.0698$, found 340.0693 . 


\section{3-3. Synthesis of Compound 13}

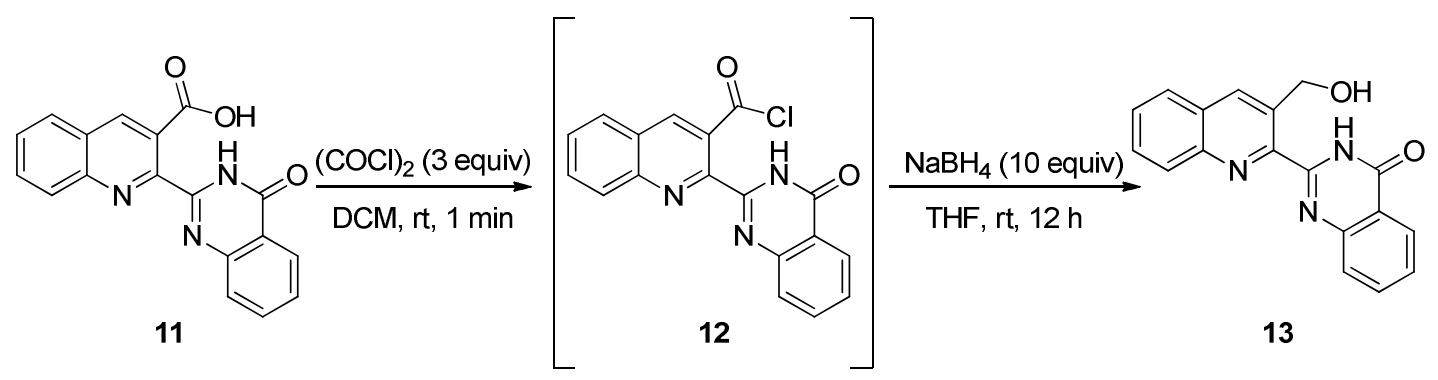

To a stirred solution of compound $11(0.40 \mathrm{mmol}, 0.13 \mathrm{~g})$ in dichloromethane $(4.0 \mathrm{~mL})$ was added oxalyl chloride $(1.2 \mathrm{mmol}, 0.10 \mathrm{~mL})$. The reaction mixture was stirred at room temperature and monitored by TLC. Upon the complete addition of oxalyl chloride to the reaction mixture, compound 11 was completely consumed. The reaction mixture was concentrated in vacuo to remove the remaining oxalyl chloride leading to the corresponding acyl chloride $\mathbf{1 2}$ as a yellow solid. Without further purification of compound 12, the resulting compound $\mathbf{1 2}$ was dissolved in THF (4.0 mL). Sodium borohydride powder $(4.0 \mathrm{mmol}, 0.15 \mathrm{~g})$ was added to the above solution at room temperature. The reaction mixture was stirred at room temperature and monitored by TLC. After the complete consumption of the resulting acid chloride 12, the reaction mixture was quenched with saturated aqueous solution of $\mathrm{NH}_{4} \mathrm{Cl}$ and extracted with ethyl acetate. The organic layer was combined, dried over anhydrous $\mathrm{MgSO}_{4}$, and concentrated in vacuo. The residue was purified by column chromatography on silica (ethyl acetate:hexanes $=1: 1$ ) to afford the desired product $\mathbf{1 3}$ as a white solid in $94 \%$ yield $(0.11 \mathrm{~g})$ over 2 steps.

Spectroscopic data were in good agreement with the literature. ${ }^{4}$

${ }^{1} \mathrm{H}$ NMR $\left(500 \mathrm{MHz}, \mathrm{CDCl}_{3}, \mathrm{ppm}\right) \delta 11.48(\mathrm{br}, 1 \mathrm{H}), 8.41(\mathrm{~d}, J=8.4 \mathrm{~Hz}, 1 \mathrm{H}), 8.31(\mathrm{~s}, 1 \mathrm{H}), 8.19(\mathrm{~d}, J=$ $8.4 \mathrm{~Hz}, 1 \mathrm{H}), 7.92(\mathrm{~d}, J=8.1 \mathrm{~Hz}, 1 \mathrm{H}), 7.82-7.89$ (m, 3H), 7.69 (ddd, $J=7.9,7.0,0.9 \mathrm{~Hz}, 1 \mathrm{H}), 7.61$ (ddd, $J=7.9,6.2,1.9 \mathrm{~Hz}, 1 \mathrm{H}), 6.36(\mathrm{t}, J=7.7 \mathrm{~Hz}, 1 \mathrm{H}), 5.09$ (d, $J=7.6 \mathrm{~Hz}, 2 \mathrm{H})$.

${ }^{13} \mathrm{C}$ NMR (125 MHz, $\mathrm{CDCl}_{3}$, ppm) $\delta 161.2,150.2,148.0,146.7,146.1,139.5,135.1,134.1,131.0$, $129.5,129.3129 .1,128.4,127.9,127.7,127.1,122.6,64.1$. 


\section{3-4. Synthesis of Luotonin A (2)}<smiles>O=c1[nH]c(-c2nc3ccccc3cc2CO)nc2ccccc12</smiles>

13
$\mathrm{PPh}_{3}(2.0$ equiv)

DIAD (2.0 equiv)

THF, rt, $1 \mathrm{~h}$

To a solution of compound $13(30 \mathrm{mg}, 0.10 \mathrm{mmol})$ and triphenylphosphine $(52 \mathrm{mg}, 0.20 \mathrm{mmol})$ in THF $(1.0 \mathrm{~mL})$ was added DIAD $(39 \mu \mathrm{L}, 0.20 \mathrm{mmol})$. The reaction mixture was stirred at room temperature and monitored by TLC. After complete consumption of compound 13, the desired product (2) was precipitated in the reaction mixture. The precipitation was collected by filtration to provide luotonin A (2) as a white crystal in $45 \%$ yield. The filtrate was further purified by column chromatography on silica (ethyl acetate:hexanes $=1: 1$ ) to afford the desired product 2 in $48 \%$ yield. (overall yield : 93\% yield, $24 \mathrm{mg}$ ).

Spectroscopic data were in good agreement with the literature. ${ }^{4}$

${ }^{1} \mathrm{H}$ NMR $\left(500 \mathrm{MHz}, \mathrm{CDCl}_{3}, \mathrm{ppm}\right) \delta 8.50(\mathrm{~d}, J=8.5 \mathrm{~Hz}, 1 \mathrm{H}), 8.48(\mathrm{~s}, 1 \mathrm{H}), 8.46(\mathrm{dd}, J=7.9,1.2 \mathrm{~Hz}$, $1 \mathrm{H}), 8.14(\mathrm{~d}, J=8.1 \mathrm{~Hz}, 1 \mathrm{H}), 7.98(\mathrm{~d}, J=8.2 \mathrm{~Hz}, 1 \mathrm{H}), 7.88(\mathrm{t}, J=7.0 \mathrm{~Hz}, 1 \mathrm{H}), 7.87$ (t, $J=7.2 \mathrm{~Hz}$, $1 \mathrm{H}), 7.69$ - $7.74(\mathrm{td}, J=7.5,1.1 \mathrm{~Hz}, 1 \mathrm{H}), 7.60(\mathrm{td}, J=7.6,1.1 \mathrm{~Hz}, 1 \mathrm{H}), 5.37$ (s, $2 \mathrm{H})$.

${ }^{13} \mathrm{C}$ NMR $\left(125 \mathrm{MHz}, \mathrm{CDCl}_{3}\right.$, ppm) $\delta 160.8,152.7,151.4,149.6,149.5,134.7,131.7,130.9,130.8$, 129.6, 128.9, 128.7, 128.1, 127.6, 126.6, 121.5, 47.5. 


\section{References}

1. Lee, S. J.; Seo, H.-A.; Cheon, C.-H. Adv. Synth. Catal. 2016, 358, 1566.

2. Khalil, Z. H.; Koraiem, A. I. M.; El-Maghraby, M. A.; Abu-El-Hamd, R. M. J. Chem. Tech. Biotechnol. 1986, 36, 379.

3. Zhang, C.; De, C. K.; Mal, R.; Seidel, D. J. Am. Chem. Soc. 2008, 130, 416.

4. Nagarapu, L.; Gaikwad, H. K.; Bantu, R. Synlett 2012, 1775.

5. Mhaske, S. B.; Argade, N. P. J. Org. Chem. 2004, 69, 4563.

6. Li, T.; Chen, M.; Yang, L.; Xiong, Z.; Wang, Y.; Li, F.; Chen, D. Tetrahedron 2016, 72, 868. 


\section{Spectroscopic Data}

\section{5-1. NMR Spectra of Aldimine 5}

(a) ${ }^{1} \mathrm{H}$ NMR Spectrum of Aldimine 5 (in $\mathrm{CDCl}_{3}, 400 \mathrm{MHz}$ )
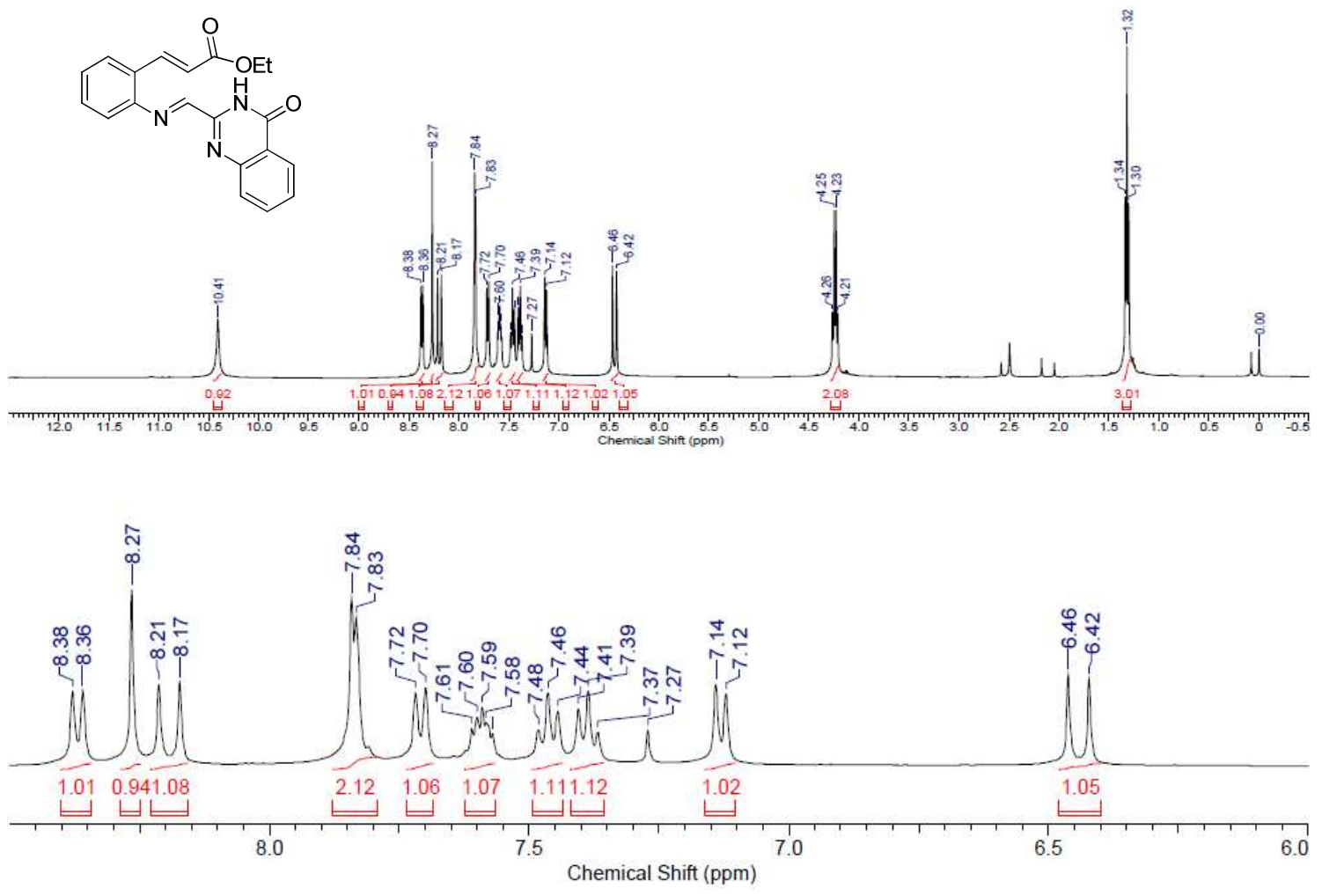

(b) ${ }^{13} \mathrm{C}$ NMR Spectrum of Aldimine 5 (in $\mathrm{CDCl}_{3}, 100 \mathrm{MHz}$ )

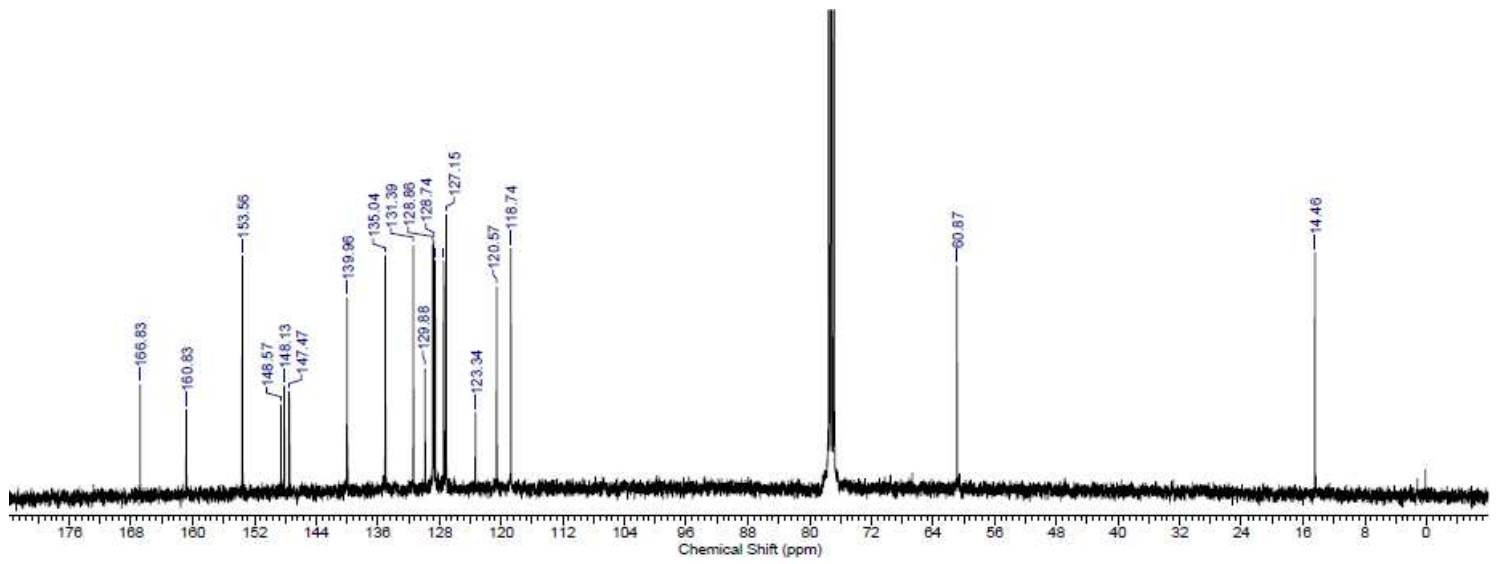




\section{5-2. NMR Spectra of Indole 3}

(a) ${ }^{1} \mathrm{H}$ NMR Spectrum of Indole 3 (in DMSO-d 6 , $400 \mathrm{MHz}$ )
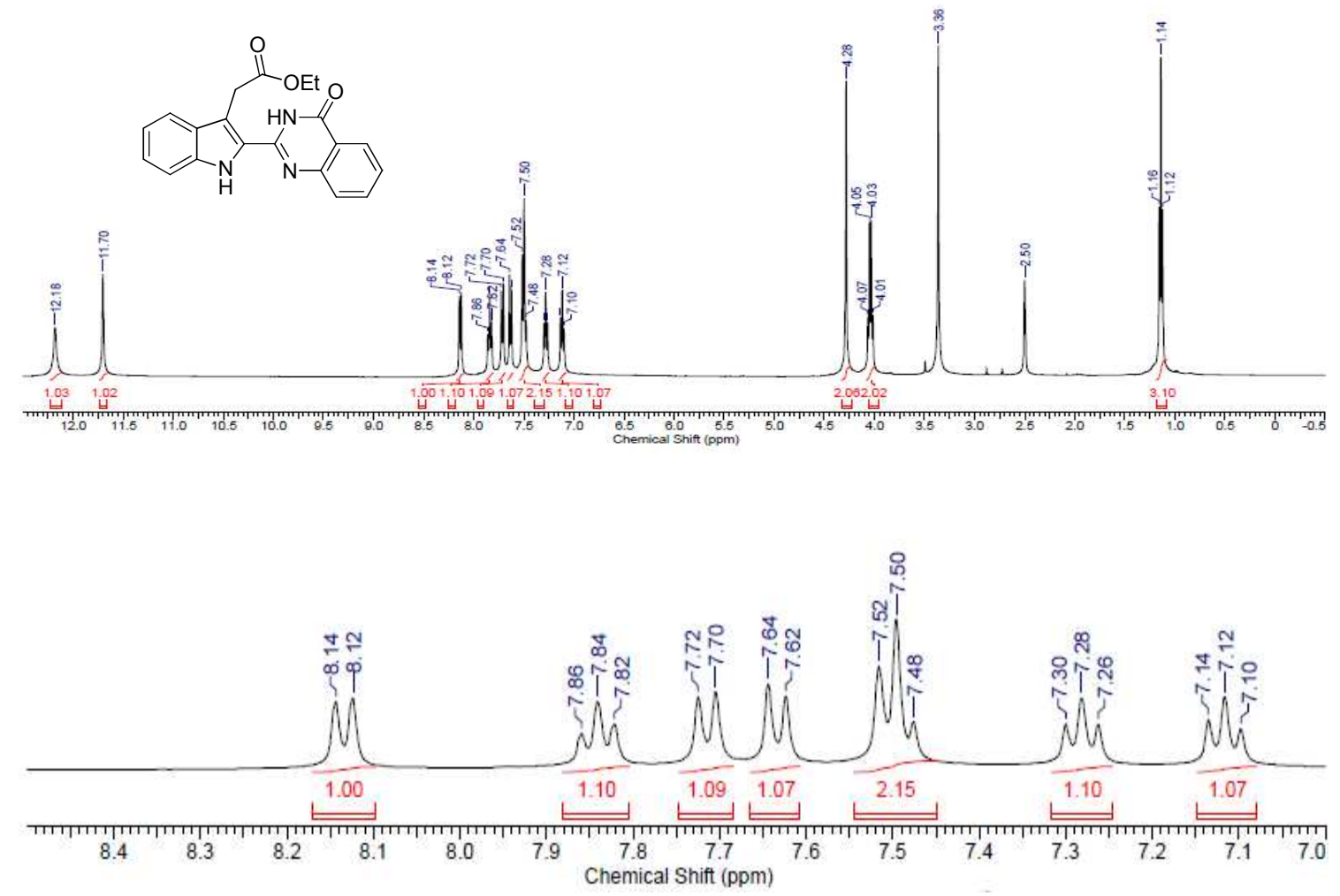

(b) ${ }^{13} \mathrm{C}$ NMR Spectrum of Indole 3 (in DMSO-d $6,100 \mathrm{MHz}$ ))

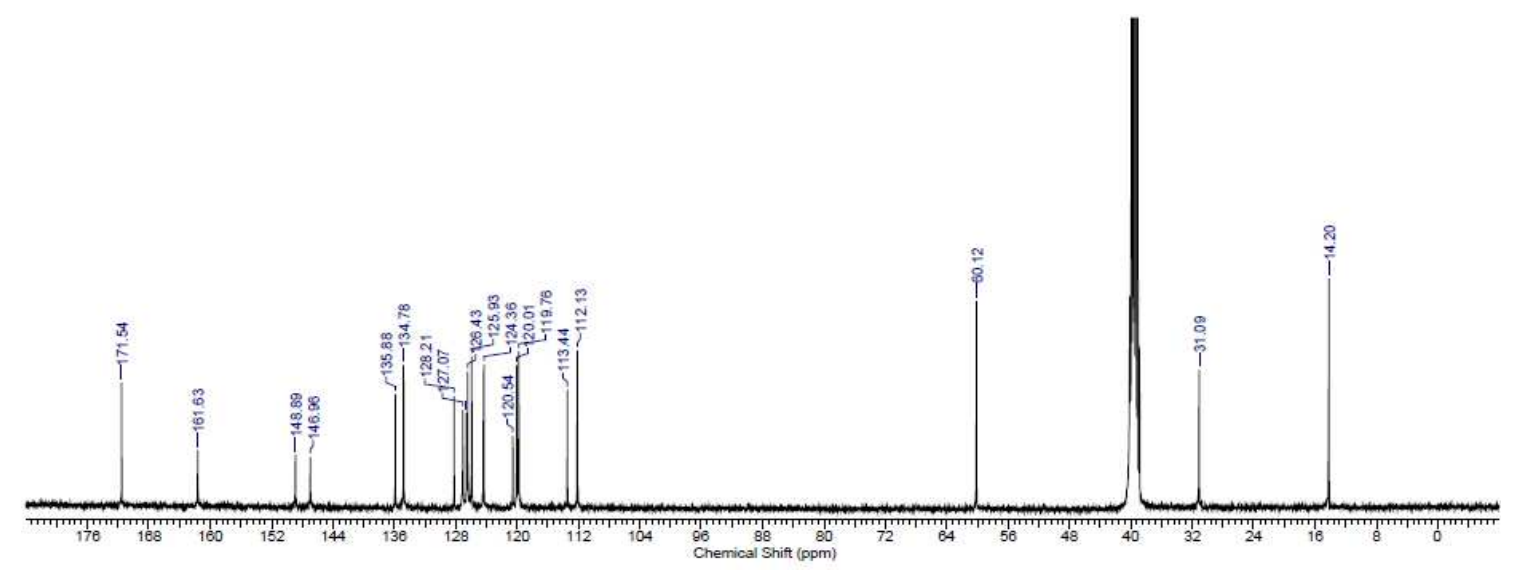




\section{5-3. NMR Spectra of Compound 8}

(a) ${ }^{1} \mathrm{H}$ NMR Spectrum of Compound 8 (in DMSO-d 6 , $500 \mathrm{MHz}$ )
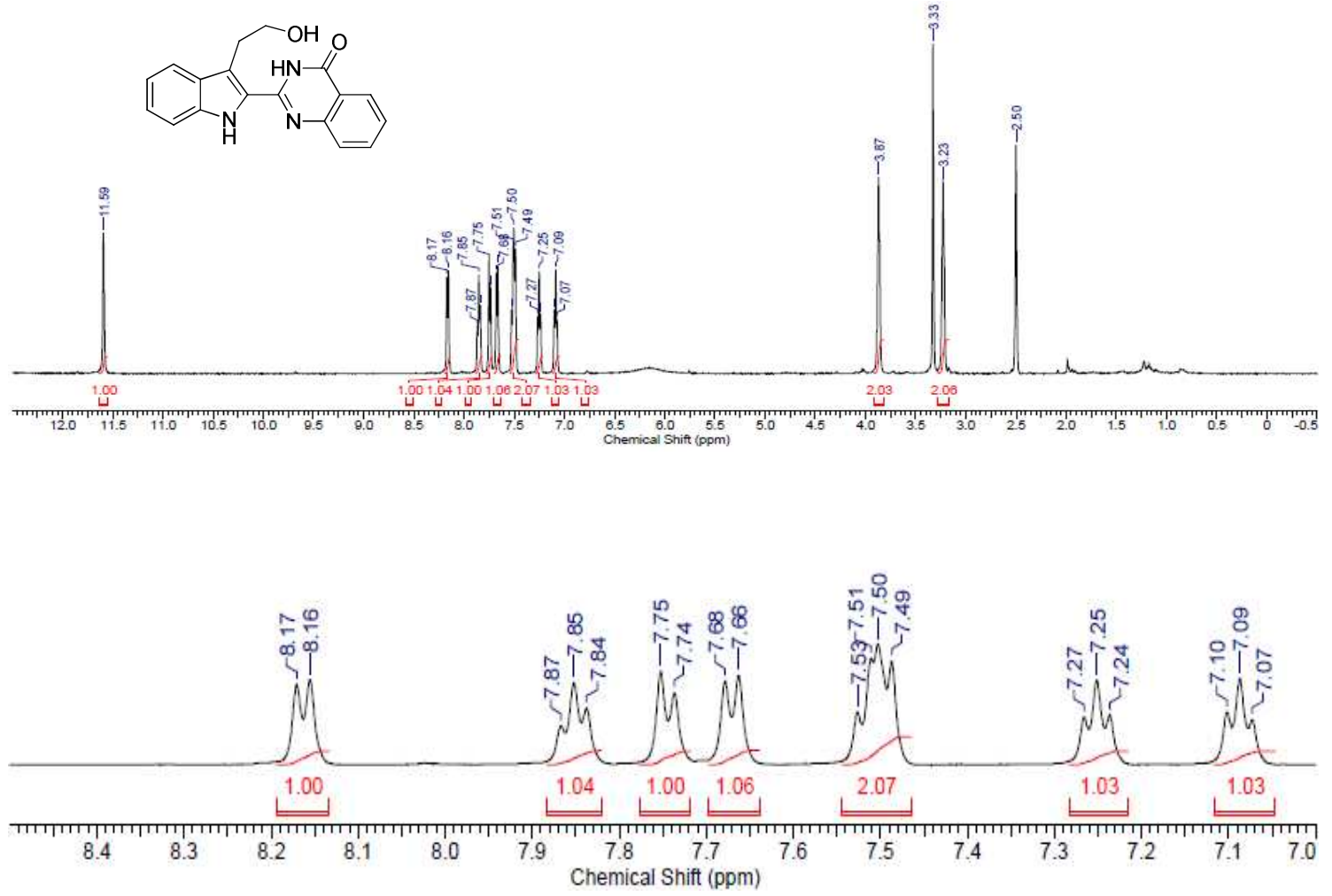

(b) ${ }^{13} \mathrm{C}$ NMR Spectrum of Compound 8 (in DMSO- $\mathrm{d}_{6}, 125 \mathrm{MHz}$ )

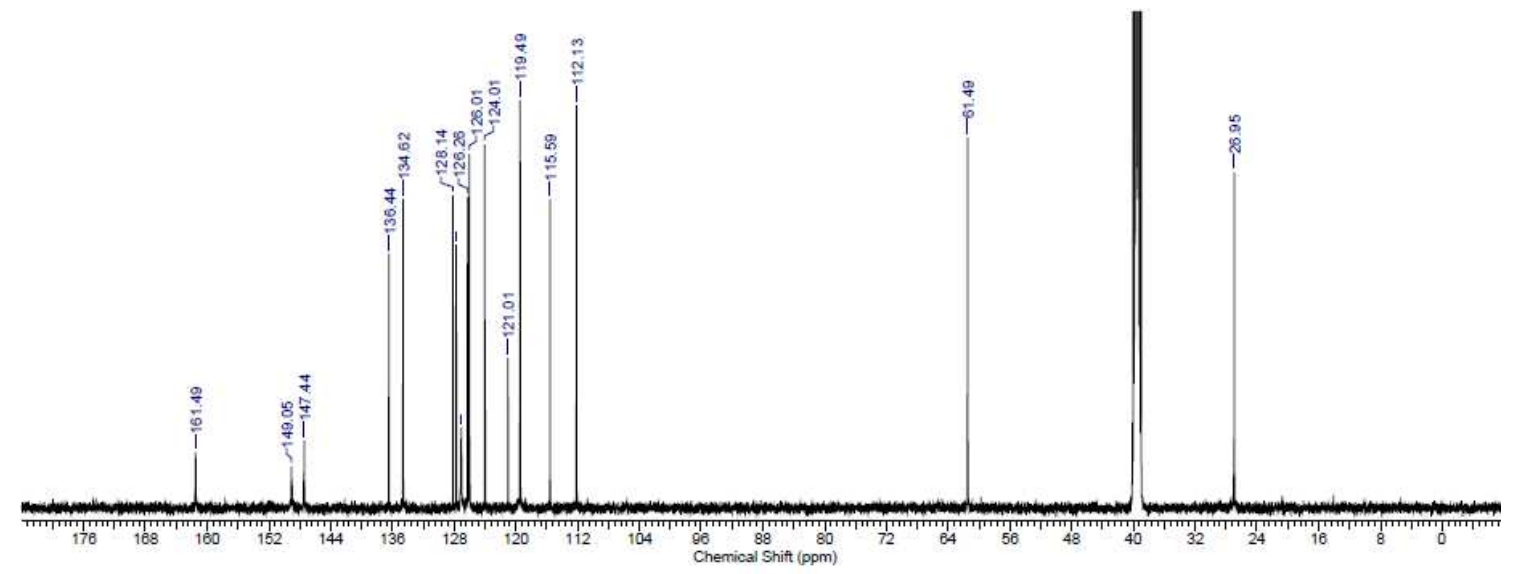




\section{5-4. NMR Spectra of Rutaecarpine (1)}

(a) ${ }^{1} \mathrm{H}$ NMR Spectrum of Rutaecarpine (1) (in $\mathrm{CDCl}_{3}, 400 \mathrm{MHz}$ )

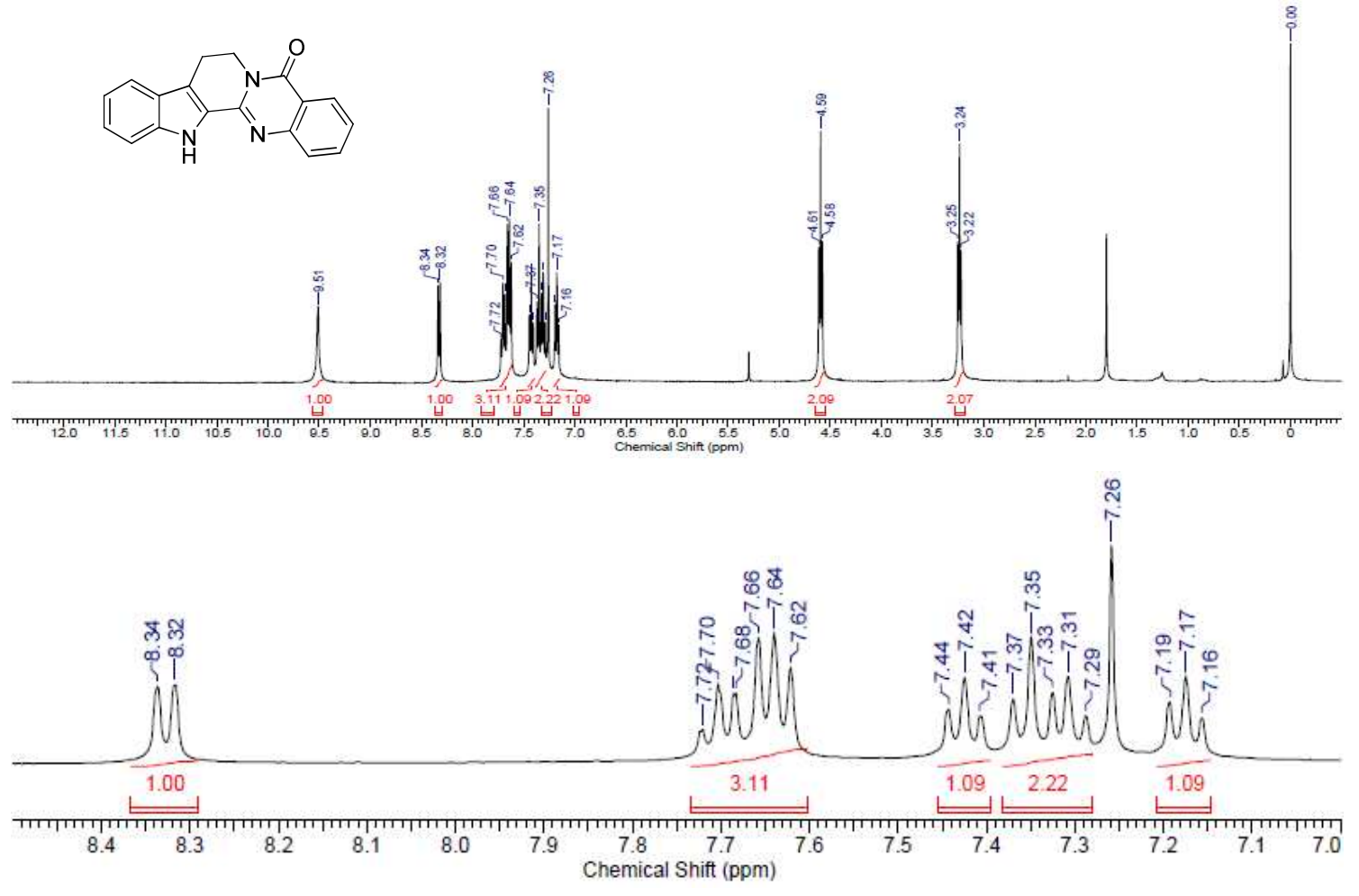

(b) ${ }^{13} \mathrm{C}$ NMR Spectrum of Rutaecarpine (1) (in $\mathrm{CDCl}_{3}, 100 \mathrm{MHz}$ )

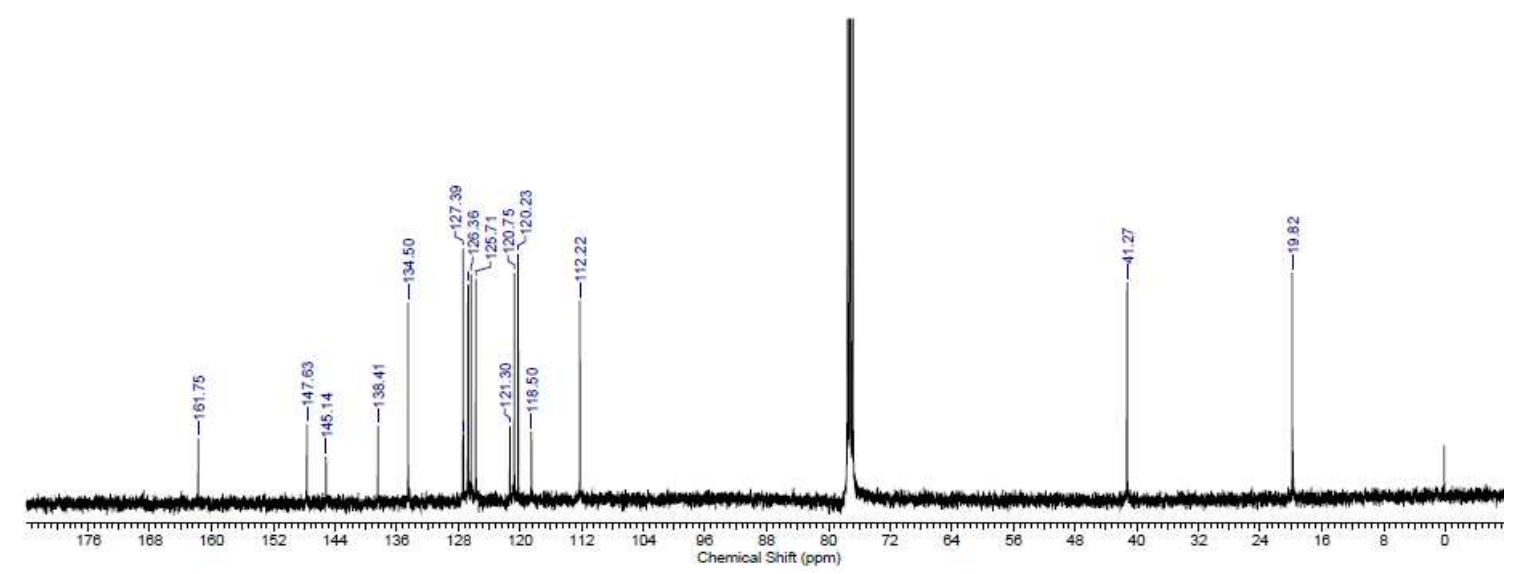




\section{5-5. NMR Spectra of Quinoline 4}

(a) ${ }^{1} \mathrm{H}$ NMR Spectrum of Quinoline 4 (in $\mathrm{CDCl}_{3}, 400 \mathrm{MHz}$ )
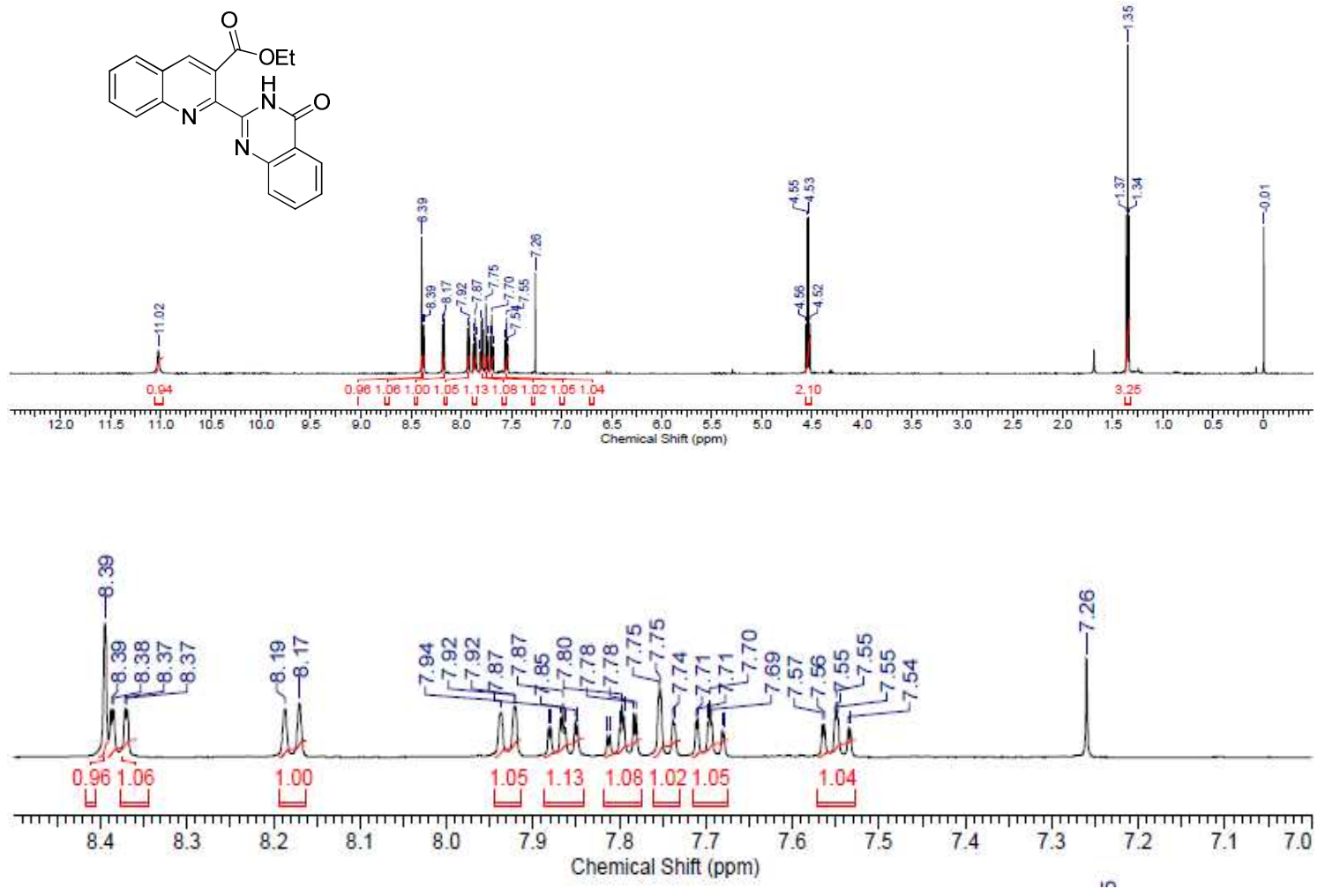

(b) ${ }^{13} \mathrm{C}$ NMR Spectrum of Quinoline 4 (in $\mathrm{CDCl}_{3}, 100 \mathrm{MHz}$ )

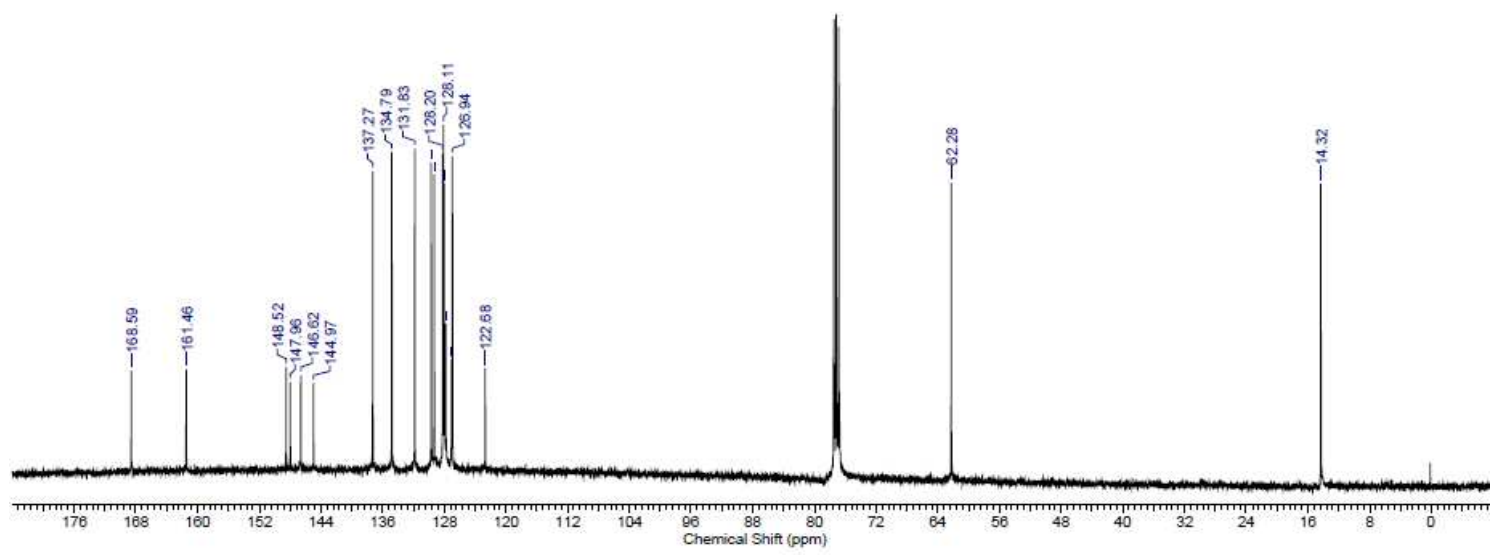




\section{5-6. NMR Spectra of Side-Products 9 and 10}

(a) ${ }^{1} \mathrm{H}$ NMR Spectrum of Side-Product 9 (in $\mathrm{CDCl}_{3}, 500 \mathrm{MHz}$ )
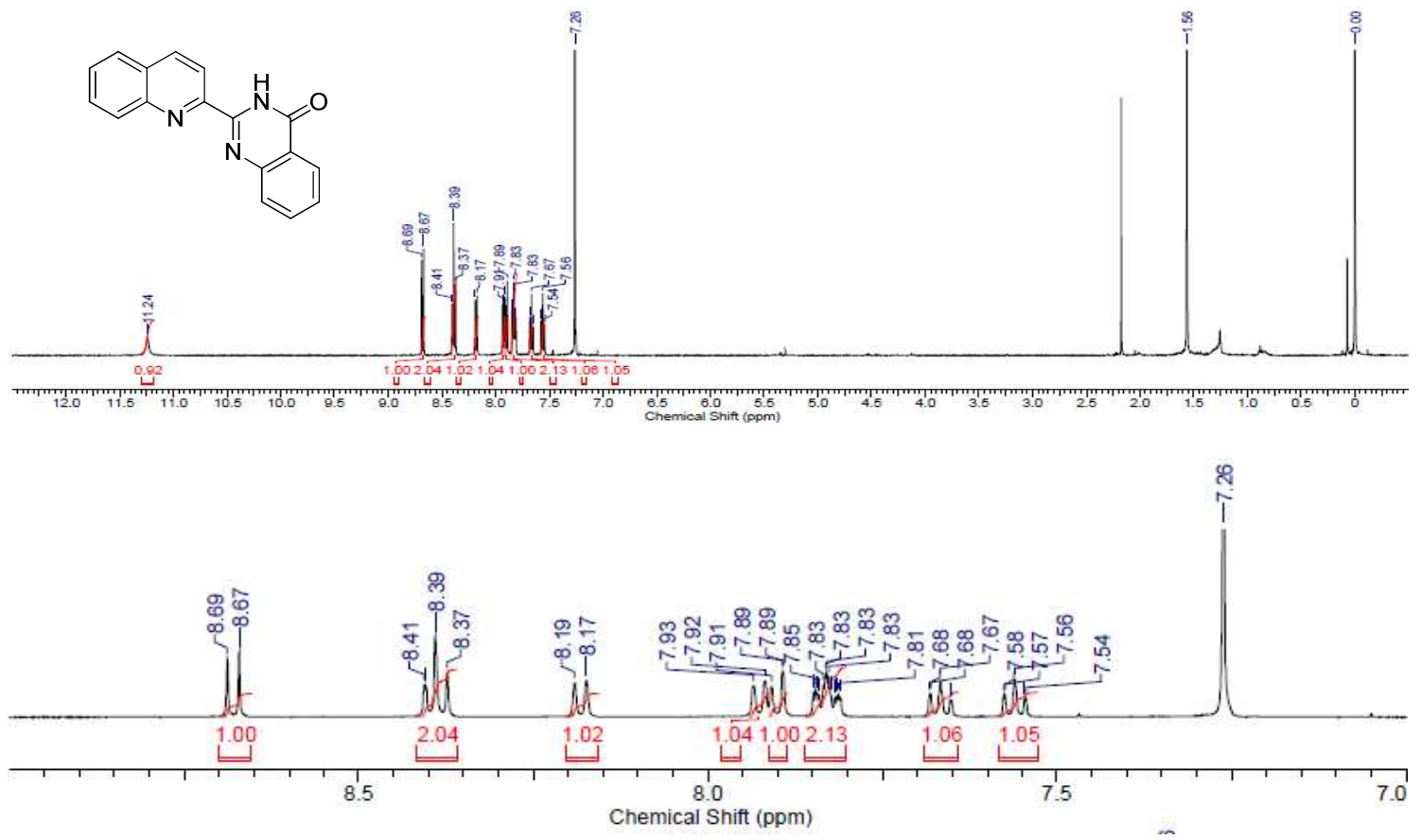

(b) ${ }^{1} \mathrm{H}$ NMR Spectrum of Side-Product 10 (in DMSO-d 6 , $500 \mathrm{MHz}$ )
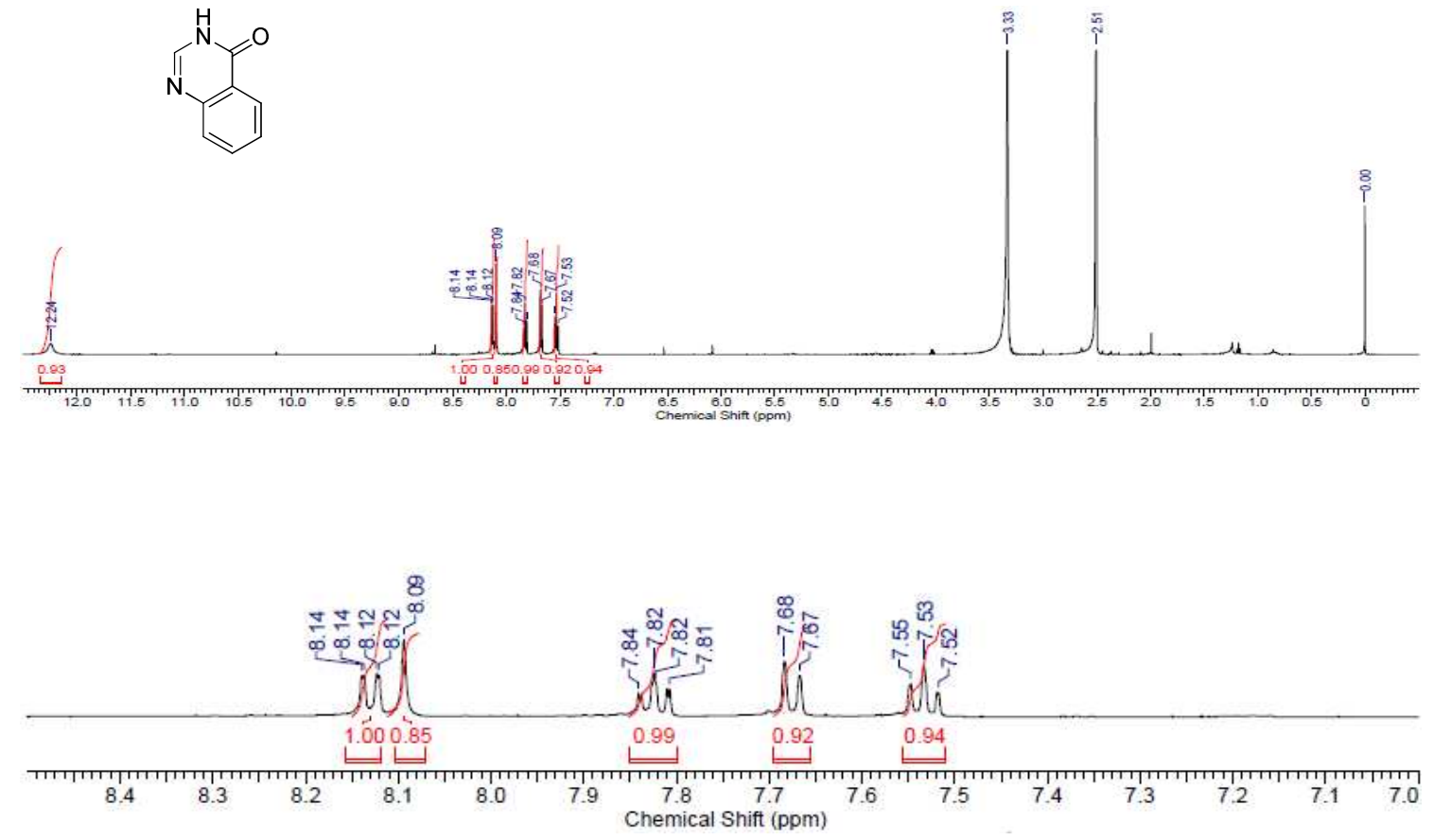


\section{5-7. NMR Spectra of Compound 11}

(a) ${ }^{1} \mathrm{H}$ NMR Spectrum of Compound 11 (in DMSO-d 6 , $500 \mathrm{MHz}$ )
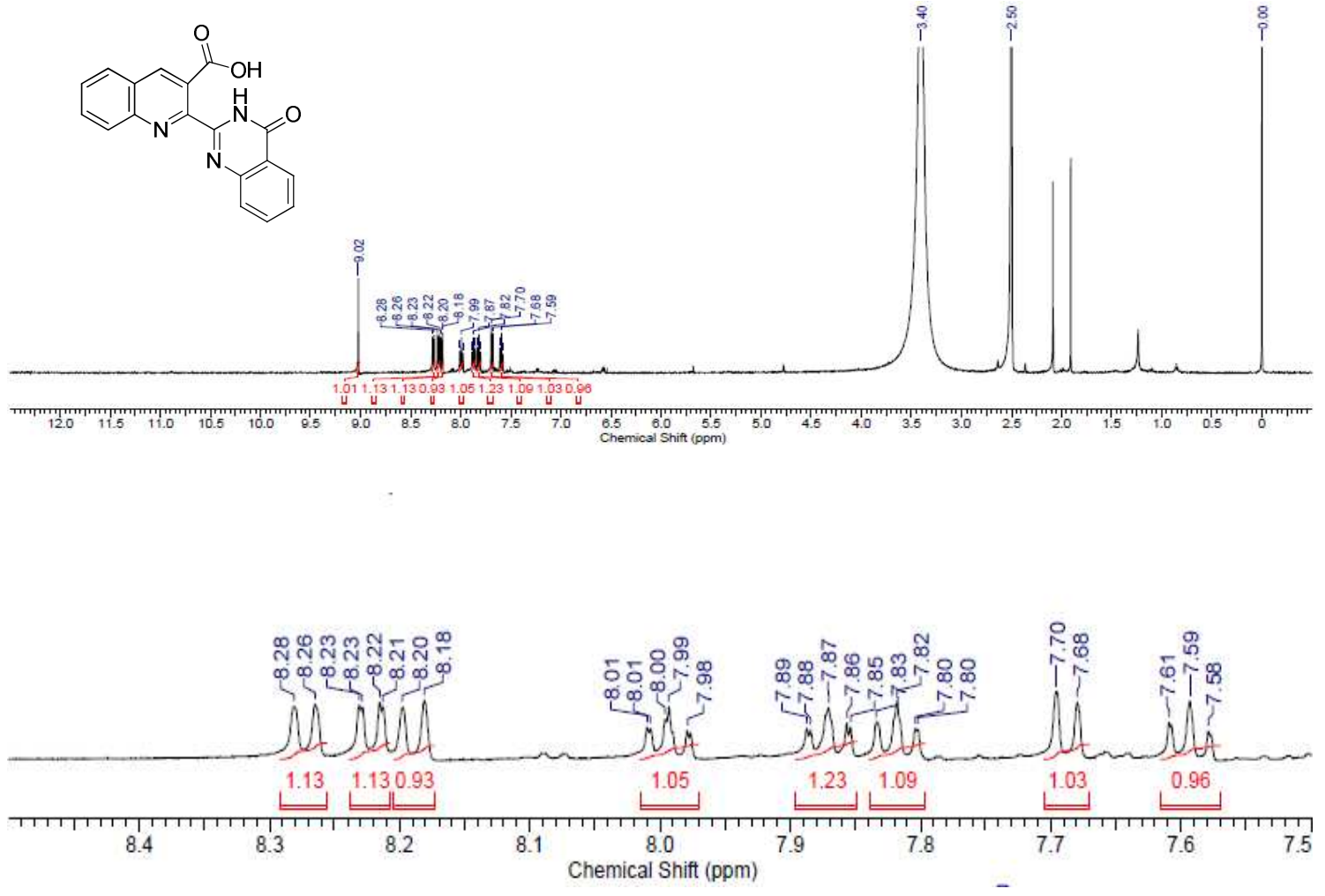

(b) ${ }^{13} \mathrm{C}$ NMR Spectrum of Compound 11 (in DMSO-d 6 , $125 \mathrm{MHz}$ )

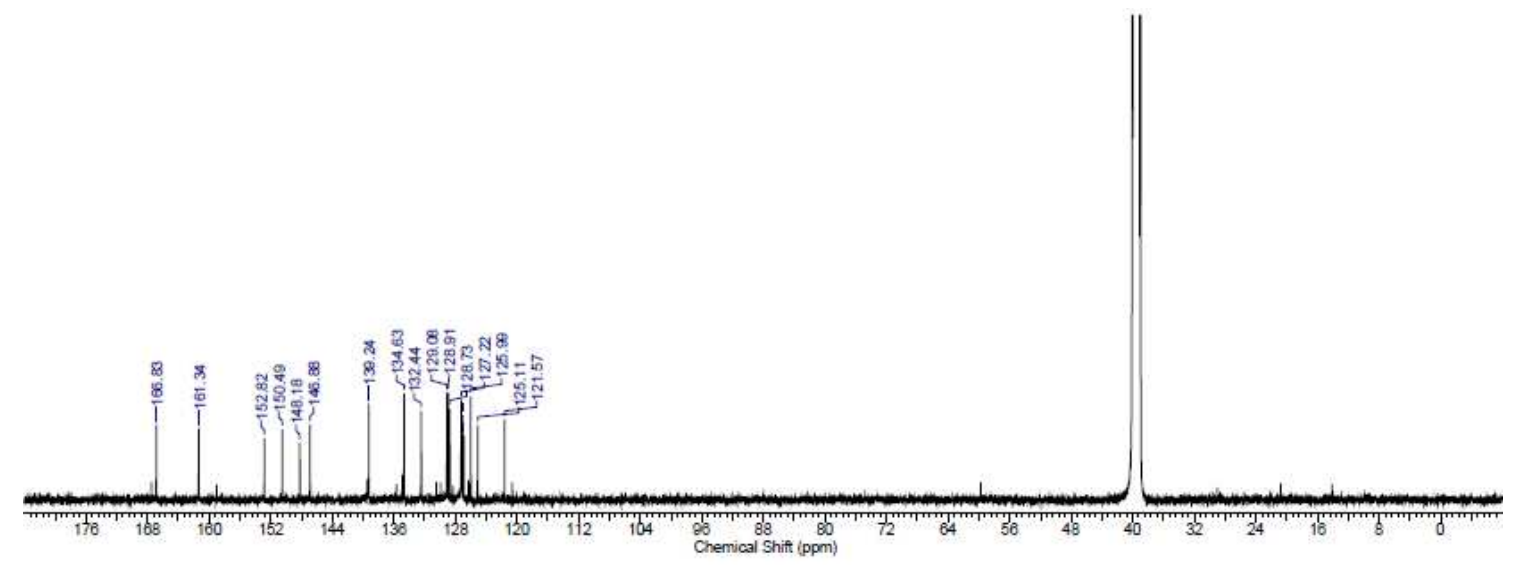




\section{5-8. NMR Spectra of Compound 13}

(a) ${ }^{1} \mathrm{H}$ NMR Spectrum of Compound 13 (in $\mathrm{CDCl}_{3}, 500 \mathrm{MHz}$ )
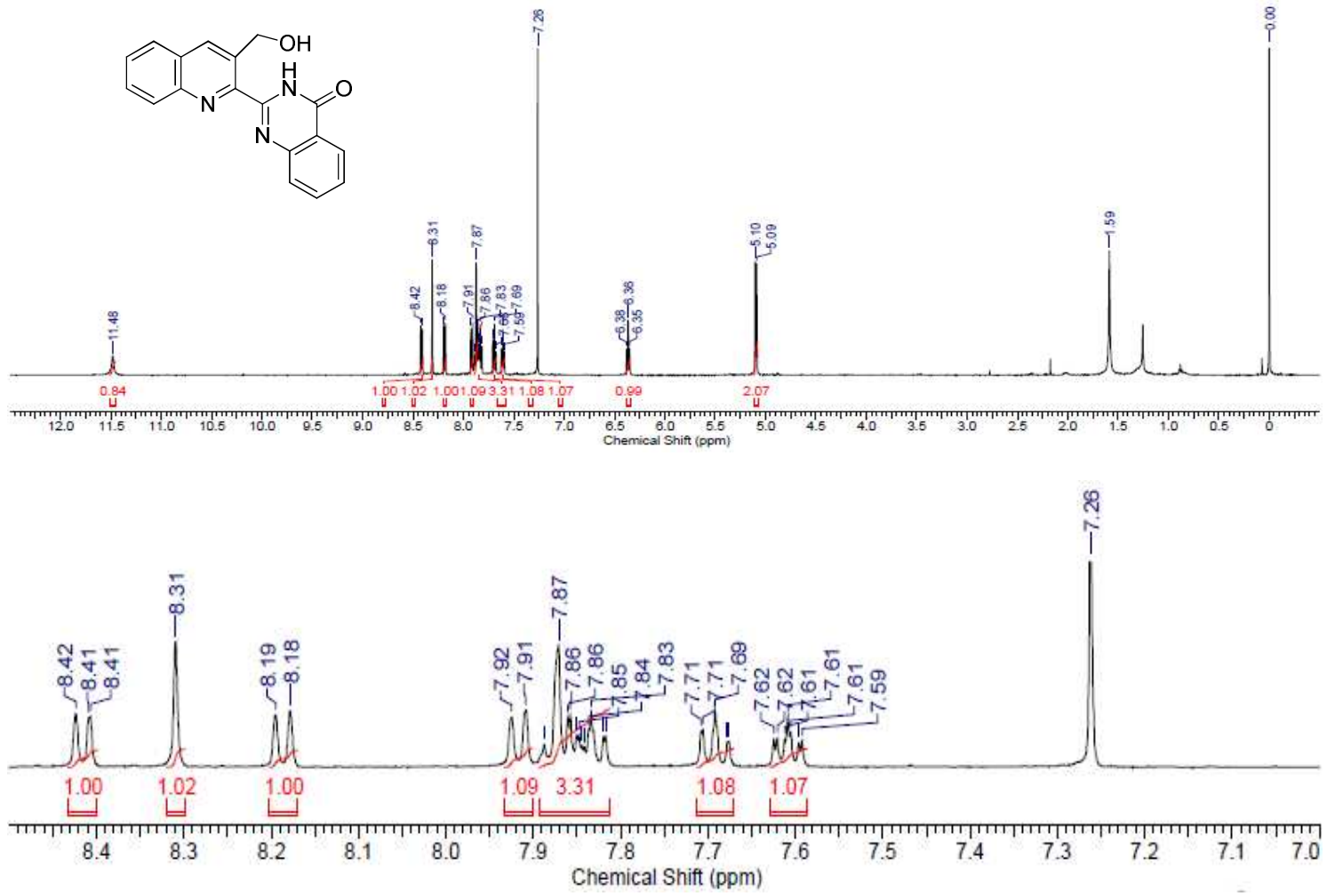

(b) ${ }^{13} \mathrm{C}$ NMR Spectrum of Compound 13 (in $\mathrm{CDCl}_{3}, 125 \mathrm{MHz}$ )

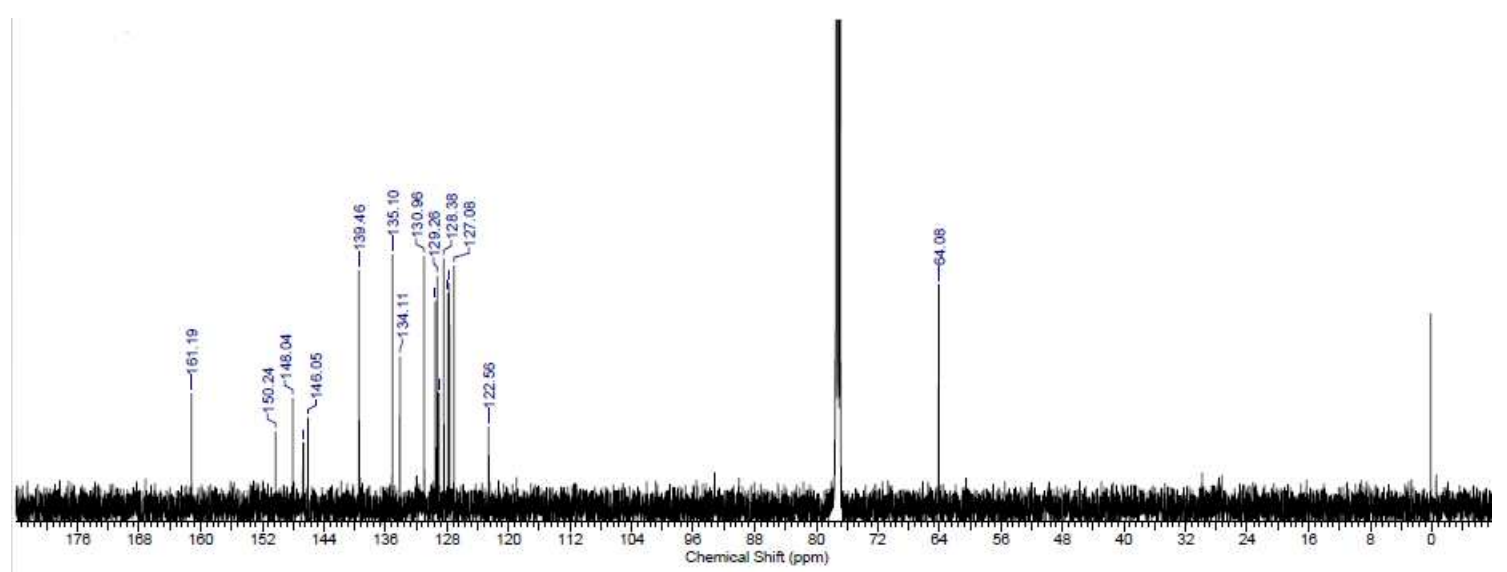




\section{5-9. NMR Spectra of Luotonin A (2)}

(a) ${ }^{1} \mathrm{H}$ NMR Spectrum of Luotonin A (2) (in $\mathrm{CDCl}_{3}, 500 \mathrm{MHz}$ )
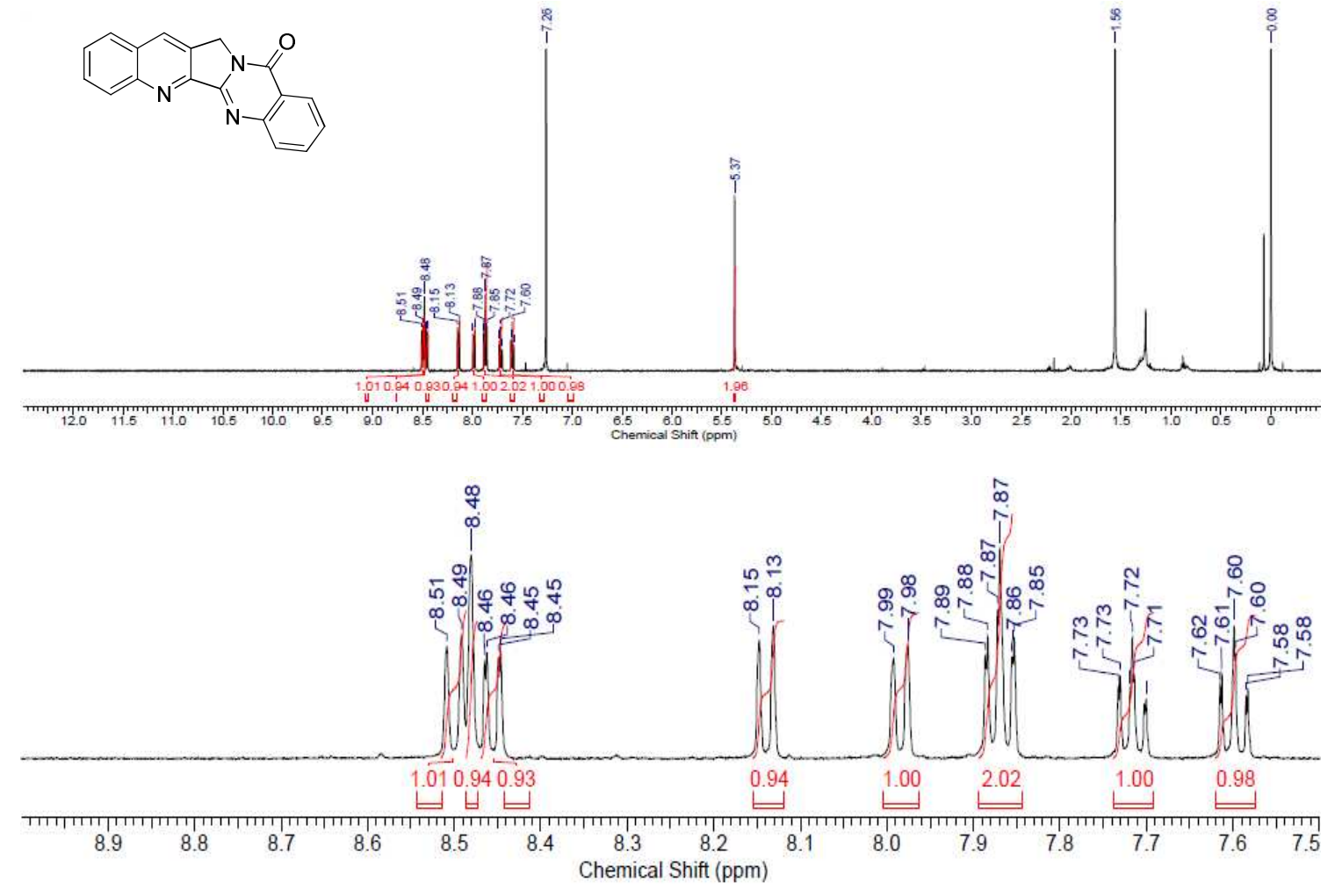

(b) ${ }^{13} \mathrm{C}$ NMR Spectrum of Luotonin A (2) (in $\mathrm{CDCl}_{3}, 125 \mathrm{MHz}$ )

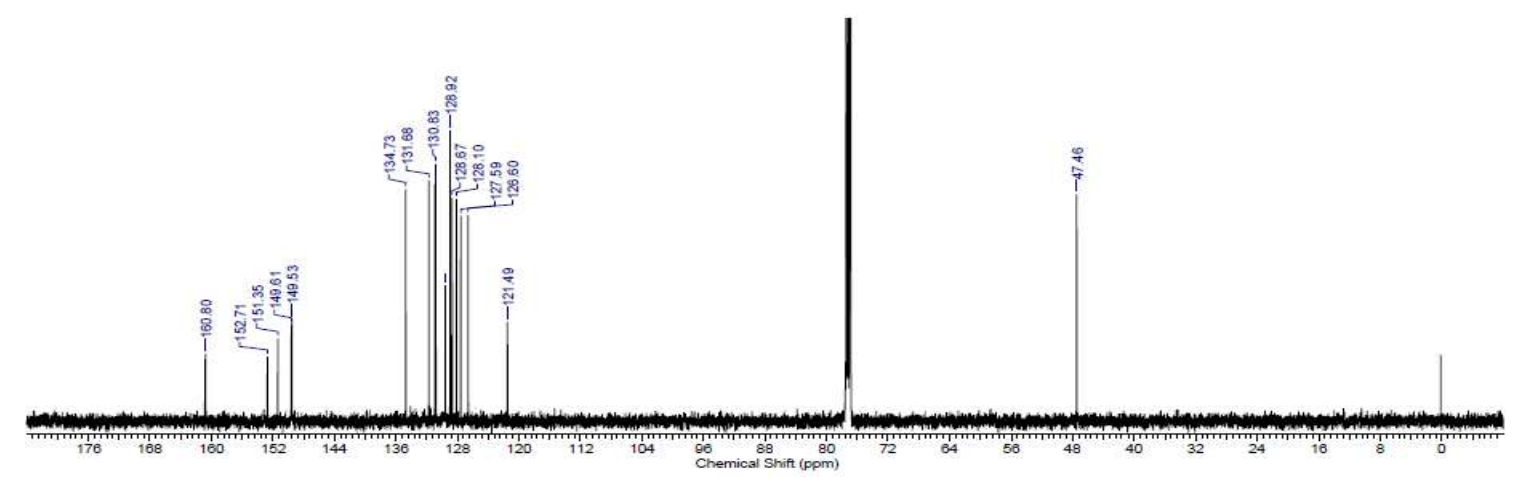

